\title{
Implementasi Aplikasi Database Untuk Mendukung Sistem Smart card Di STKIP Muhammadiyah Bone
}

\author{
Andani Achmad ${ }^{1}$, Syafruddin Syarif ${ }^{1}$, Zulfajri B. Hasanuddin ${ }^{1}$, Rhiza S. Sadjad ${ }^{1}$, Muh. Anshar ${ }^{1}, Z_{\text {Zaenab }}$ \\ Muslimin ${ }^{1}$, Andini D. Achmad ${ }^{1}$, Indrabayu ${ }^{2}$, \\ Departemen Teknik Elektro*, Fakultas Teknik UNHAS ${ }^{1}$ \\ Departemen Teknik Informatika, Fakultas Teknik UNHAS ${ }^{2}$ \\ andani60@yahoo.com ${ }^{1 *}$
}

\begin{abstract}
Abstrak
Smart campus mengacu pada fasilitas-fasilitas kampus pendukung semua kegiatan sivitas akademika dalam melaksanakan kewajiban Tridarma Perguruan Tinggi yang menggunakan teknologi informasi sebagai tulang punggung pendukung. STKIP Muhammadiyah Bone dipilih menjadi mitra dalam program pengabdian kepada masyarakat. Dalam rangka menyongsong suatu transformasi, kampus akan mengarahkan pelayanannya dengan berbasis teknologi. Jika saat ini layanan seperti registrasi mahasiswa, absensi masih bersifat manual, dimana mahasiswa datang dan melakukan absensi secara manual, ke depan hal itu akan diubah menjadi sistem elektronik. Namun, dikampus STKIP Muhammadiyah Bone ini masih belum mengaplikasikan sistem smart campus ini. Dengan solusi yang ditawarkan dengan dibuat suatu sosialisasi dan pelatihan mengenai Smart card dan implementasi databasenya. Dimana setelah dilakukan sosialisasi dan pelatihan secara menyeluruh baik keseluruhan (solusi total), mencakup perangkat keras, perangkat lunak, dan perangkat prosedur dan tata kerja, dalam rangka mendukung operasional kampus yang akan bertransformasi menjadi Smart campus dapat dilakukan pengembangan mandiri oleh pihak kampus sendiri. Kegiatan ini dilaksanakan selama satu hari dan berjalan dengan lancar dilihat dari antusiasme dari pihak jajaran staf kampus dan mahasiswa yang mengikuti kegiatan ini serta dilakukannya instalasi dua buah unit sistem smartcard pada ruang rektor dan wakil rektor.
\end{abstract}

Kata Kunci: Pengabdian masyarakat; smart card, smart campus; database; administrasi kampus.

\begin{abstract}
Smart campus refers to campus facilities which are supporting all activities of the academics in carrying out the obligations of the Tridarma Perguruan Tinggi using information technology as the backbone. STKIP Muhammadiyah Bone was chosen as a partner in the community service program. In order to welcome a transformation, the campus will direct its services with technology. Currently services such as student registration, attendance input is still done mannually, in the future it will be converted into an electronic system. However, in STKIP Muhammadiyah Bone, it has not applied smart campus system. The proposed solution is to make Smart cards socialization and training and database implementation. After thorough socialization and training which includes hardware, software, procedures and work procedures, furthermore, independent development is carried out by the campus itself. This activity was held for one day and went smoothly judging from the enthusiasm of the staff and students who participated in this activity and the installation of two smartcard systems in the rector and vice rector rooms.
\end{abstract}

Keywords: Community service; smart card, smart campus; database; campus administration.

\section{Pendahuluan}

Pemerintah daerah Kabupaten Bone telah membangun beberapa universitas baik negeri maupun swasta. Seperti contohnya Politeknik Teknologi Negeri Bone, Politeknik Kelautan dan Perikanan Negeri Bone, Sekolah Tinggi Ilmu Administrasi dan STKIP Muhammadiyah Bone yang menjadi mitra program pengabdian masyarakat UNHAS serta masih banyak lagi. STKIP Muhammadiyah Bone berdiri pada tanggal 1 Desember 1973 yang merupakan awal dari cabang Fakultas Ilmu Pendidikan Unismuh Makassar berdasarkan Akta Notaris Nomor 71 tanggal 19 Juni 1963 yang 
dikelolah oleh Majelis Pendidikan Muhammadiyah. Kemudian, STKIP Muhammadiyah Bone berdiri sendiri sebagai Sekolah Tinggi pada tanggal 19 Januari 1979 dengan status "terdaftar" jenjang sarjana muda dan pada tahun 1986 menjadi jenjang Sarjana Strata Satu (S1). Kampus ini berada di Jln. Abu Daeng Pasolong No. 62 Kabupaten Bone Sulawesi Selatan. Adapun jumlah mahasiswa yang aktif sampai tahun 2018 yakni 1500 lebih mahasiswa yang terdiri dari beberapa jurusan yakni jurusan Matematika dan Pengetahuan Alam, Jurusan Ilmu Pendidikan, Jurusan Pendidikan Bahasa dan Seni, dan Jurusan Ilmu Pendidikan Sosial. Adapun jumlah alumni yang telah dihasilkan sebanyak 15105 orang yang sudah tersebar di berbagai daerah di Indonesia. Baik itu bekerja sebagai PNS maupun berkerja di BUMN. Sekolah Tinggi ini merupakan salah satu kampus besar di Kabupaten Bone. Adapun STKIP Muhammadiyah Bone ini memiliki tenaga pengajar sebanyak 90 orang, 87 dosen yayasan dan 3 dosen dipekerjakan (DPK) dimana 5 orang sudah S3 dan selebihnya berada pada jenjang S2. Untuk Kampus STKIP Muhammadiyah Bone ini, konsep smart campus belum menyentuk ke sistem smart campus khususnya penggunaan smart card untuk berbagai aplikasi seperti halnya pada program kerjasama ini untuk dilakukan sosialisasi dan pengenalan implementasi aplikasi database untuk mendukung sistem smart campus tekhusus pada smart card di STKIP Muhammadiyah Bone ini.

Smart campus mengacu pada fasilitas-fasilitas kampus pendukung semua kegiatan sivitas akademika dalam melaksanakan kewajiban Tridarma Perguruan Tinggi yang menggunakan teknologi informasi sebagai tulang punggung pendukung. Implementasi teknologi smart campus secara miniature akhirnya muncul seperti smart class room, smart laboratory, smart bulding, smart department atau smart faculty (Dharma Putra, 2017). Salah satu domainnya, Tri Dharma Perguruan Tinggi yang mungkin ditingkatkan dalam pelayanan dan efisiensi menggunakan teknologi dalam lingkungan smart campus adalah domain pendidikan. Penerapan sistem teknologi dalam pengelolaan bidang pendidikan akan meningkatkan efiiensi dan kepuasan pemangku kepentingan. Pendidikan adalah usaha sadar dan terencana untuk mewujudkan suasana belajar dan proses pembelajaran agar peserta didik aktif mengembangkan dirinya untuk memiliki kekuatan pengedalian diri, kepribadian, kecerdasan, dan ketermpilan yang diperlukan dirinya, msayarakat, bangsa dan Negara (Wibawa, 2017).

Selain meningkatkan kualitas layanan pendidikan di kampus kepada mahasiswa, konsep smart campus juga terkait dengan upaya meningkatkan kualitas pendidikan yang ditawarkan oleh masing-masing kampus. Hal ini karena konsep smart campus menuntut implementasi langsung dari ilmu-ilmu yang dipelajari di kampus. Sehingga keberhasilan konsep smart campus seharusnya sejalan dengan keberhasilan kualitas pendidikan yang disampaikan dalam materi-materi perkualiahan.

Pada kegiatan ini, mitra pengabdian kami adalah seluruh civitas akademika Kampus STKIP Muhammadiyah Bone. Selain sebagai tempat pelaksanaan sosialisasi dan pelatihan terkait implementasi aplikasi database untuk mendukung sistem smart card di kampus ini, pihak sekolah juga menyediakan fasilitas berupa ruang pelatihan dan LCD. Dalam rangka menyongsong suatu transformasi, kampus akan mengarahkan pelayanannya dengan berbasis teknologi. Jika saat ini layanan seperti registrasi mahasiswa, absensi masih bersifat manual, dimana mahasiswa datang dan melakukan absensi secara manual, ke depan hal itu akan diubah menjadi sistem elektronik. Terobosan yang dapat dilakukan yakni menuju smart campus adalah penggunaan sistem Smart card yang dapat melakukan olah, rekap dan visualisai data absensi secara mudah. Oleh karena itu, perlu dibuat suatu sosialisasi dan pelatihan mengenai Smart card dan implementasi databasenya. 
Kegiatan pengabdian ini merupakan salah satu bentuk sosialisasi dan pelatihan terkait implementasi smart card secara keseluruhan mencakup perangkat keras, perangkat lunak, dan tata kerja untuk mendukung operasional kampus menuju sistem smart campus dan diharapkan dapat dilakukan pengembangan smart card oleh pihak kampus STKIP Muhammadiyah Bone

\section{Latar Belakang Teori}

Ruang lingkup kegiatan akademik dengan berbasis teknologi sangat didambakan setiap kampus. Dengan adanya implementasi teknologi untuk setiap kegiatan yang ada dikampus seperti administrasi, kegiatan belajar mengajar mahasiswa, manajemen energi, kepegawaian dan database mahasiswa maka dapat mempermudah dan meningkatkan kinerja sistem kampus. Saat ini, kegiatan kampus khususnya pada bagian administrasi, masih bersifat manual dalam arti belum semua terintegrasi dengan teknologi sehingga masih membutuhkan tenaga manusia yang banyak. Teknologi atau sistem yang dapat menanggulangi permasalahan ini adalah dengan menerapkan sistem smart campus. Smart campus merupakan konsep sebuah kampus yang menerapkan dan memadukan sistem pembelajaran dengan penggunaan teknologi informasi. Seperti contohnya pada penerimaan mahasiswa baru yang masuk setiap tahunnya. Untuk setiap kampus yang memiliki jumlah jurusan banyak tentunya memiliki alokasi administrasi yang semakin banyak pula dan ini memungkinkan terjadinya kesalahan data jika masih dilakukan secara manual. Selain itu, permasalahan yang banyak muncul di berbagai kampus yakni absensi mahasiswa ataupun dosen yang masih dilakukan secara manual atau menggunakan kertas. Permasalahan ini sewajarnya dapat diselesaikan dengan menerapkan smart campus untuk tiap kampus yang ada di Indoneisa. Sehingga sistem ini bisa meningkatkan kualitas layanan pendidikan yang ada dalam ruang lingkup kampus serta terkait dengan upaya meningkatkan kualitas pendidikan yang ditawarkan oleh masing-masing kampus. Hal ini karena konsep smart campus menuntut implementasi langsung dari ilmu-ilmu yang dipelajari di kampus. Sehingga keberhasilan konsep smart campus seharusnya sejalan dengan keberhasilan kualitas pendidikan yang disampaikan dalam materi-materi perkualiahan.

Salah satu bagian dari sistem smart campus ini adalah smart card. Smart card ini menjadi salah satu solusi dari sistem smart campus yang diintegrasikan pada sistem teknologi kampus khususnya pada bagian administrasi. Dengan menggunakan smart card, sistem administrasi dapat kita kelola sesuai dengan kebutuhan. Sistem smart card yang kami miliki terdiri dari hardware, software, dan protokol smart card. Protokol smart card meliputi Key Management System (KMS) dan Card Management System (CMS) yang diimplementasikan ke dalam Operating System (OS) smart card. Semua komponen tersebut bekerja dengan komponen pendukung lainnya, seperti internet dan komputer, menjadi sistem smart card. Komponen hardware terdiri dari Smart card, Reader, PC, server, dan Network. Software berupa Host Application, Network Application dan Back End Services. Protokol komunikasi berupa komunikasis antara smart card dengan reader, reader dengan PC, lalu PC dengan server.

Sistem smart card yang akan diimplementasikan memiliki keunggulan seperti meningkatkan efektifitas dan efisiensi manajemen kampus, meningkatkan keamanan asset, meningkatkan tingkat kepuasan konsumen, dan dapat menerapkan value added service. Melalui implementasi sistem smart card ini diharapkan akan diperoleh tujuan-tujuan sebagai berikut:

- Keamanan data yang tinggi untuk mengantisipasi penyalahgunaan atau penggandaan kartu.

- Identitas tunggal terintegrasi yang memuat data dengan eligibilitas tinggi sehingga dapat menyederhanakan proses manajemen data maupun pelayanan kepada civitas akademik. 
- Kombinasi smart card dan sistem pendukung yang handal, memungkinkan banyaknya nilai tambah yang bisa ditanamkan dan dapat ditingkatkan sesuai keperluan kampus kapanpun dibutuhkan.

- Interoperabilitas dengan kampus dan aplikasi kemenristekdikti.

\section{Metode}

Adapun terobosan yang dapat dilakukan dari paparan permasalah mitra diatas yakni menuju smart campus adalah penggunaan sistem Smart card yang dapat melakukan olah, rekap dan visualisai data absensi secara mudah. Oleh karena itu, perlu dibuat suatu sosialisasi dan pelatihan mengenai Smart card dan implementasi databasenya. Pelaksanaan dilakukan selama satu hari yang terbagi atas tahapan sosialisasi tentang smart campus dan smart card dan tahapan implementasi aplikasi database untuk mendukung sistem smart card meliputi absensi mahasiswa dan dosen. Dimana setelah dilakukan sosialisasi dan pelatihan secara menyeluruh baik keseluruhan (solusi total), mencakup perangkat keras, perangkat lunak, dan perangkat prosedur dan tata kerja, dalam rangka mendukung operasional kampus yang akan bertransformasi menjadi Smart campus dapat dilakukan pengembangan mandiri oleh pihak kampus sendiri. Tujuan yang hendak dicapai dari pekerjaan ini juga adalah implementasi sistem smart card yang dikembangkan oleh produsen dalam negeri, dengan distribusi kartu dan sistem pendukungnya kepada civitas akademik STKIP Muhammadiyah Bone.

\section{Hasil dan Diskusi}

Pelaksanaan pengabdian pada masyarakat yang dilaksanakan selama satu hari ini dibagi dalam 2 tahap, yaitu tahap sosialisasi tentang smart campus khususnya smart card dan tahap pelatihan implementasi aplikasi database untuk mendukung sistem smart card. Kegiatan ini diikuti oleh jajaran petinggi kampus serta mahasiswa dari STKIP Muhammadiyah Bone. Tahap pertama yakni sosialisasi tentang smart campus khususnya smart card dilakukan dengan penjelasan tentang konsorsium smart card antar beberapa universitas yang ada di Indonesia, perkembangan penelitian smart card untuk setiap universitas hingga saat ini, khususnya perkembangan implementasi smart card yang ada di Universitas Hasanuddin serta prospek dan manfaat dari sistem ini jika diaplikasikan dalam suatu sistem kampus menuju sistem Smart campus.

Tahap kedua yakni implementasi aplikasi database. Tahap ini dilakukan oleh tim teknisi dengan menjelaskan kepada peserta pengabdian masyarakat sistem apa saja yang dapat dibuat dan diimplemetasikan sesuai kebutuhan kampus. Dimana pada sosialisasi implementasi database yang dilakukan pada kampus STKIP Muhammadiyah Bone yakni bagian absensi mahasiswa dan dosen serta cara melakukan record kartu smart card. Kegiatan ini berjalan dengan lancar karena dukungan dari pihak kampus yang antusias dengan sistem yang diimplentasikan dikampusnya. Selain sosialisasi dan implementasi sistem smart campus berbasis smart card dan database juga dilakukan instalasi dua buah unit sistem smart card dan beberapa smart card yang telah dilakukan inputan data base oleh teknisi dan pihak kampus yang telah diberikan pelatihan cara penggunaan sistem smart card. 

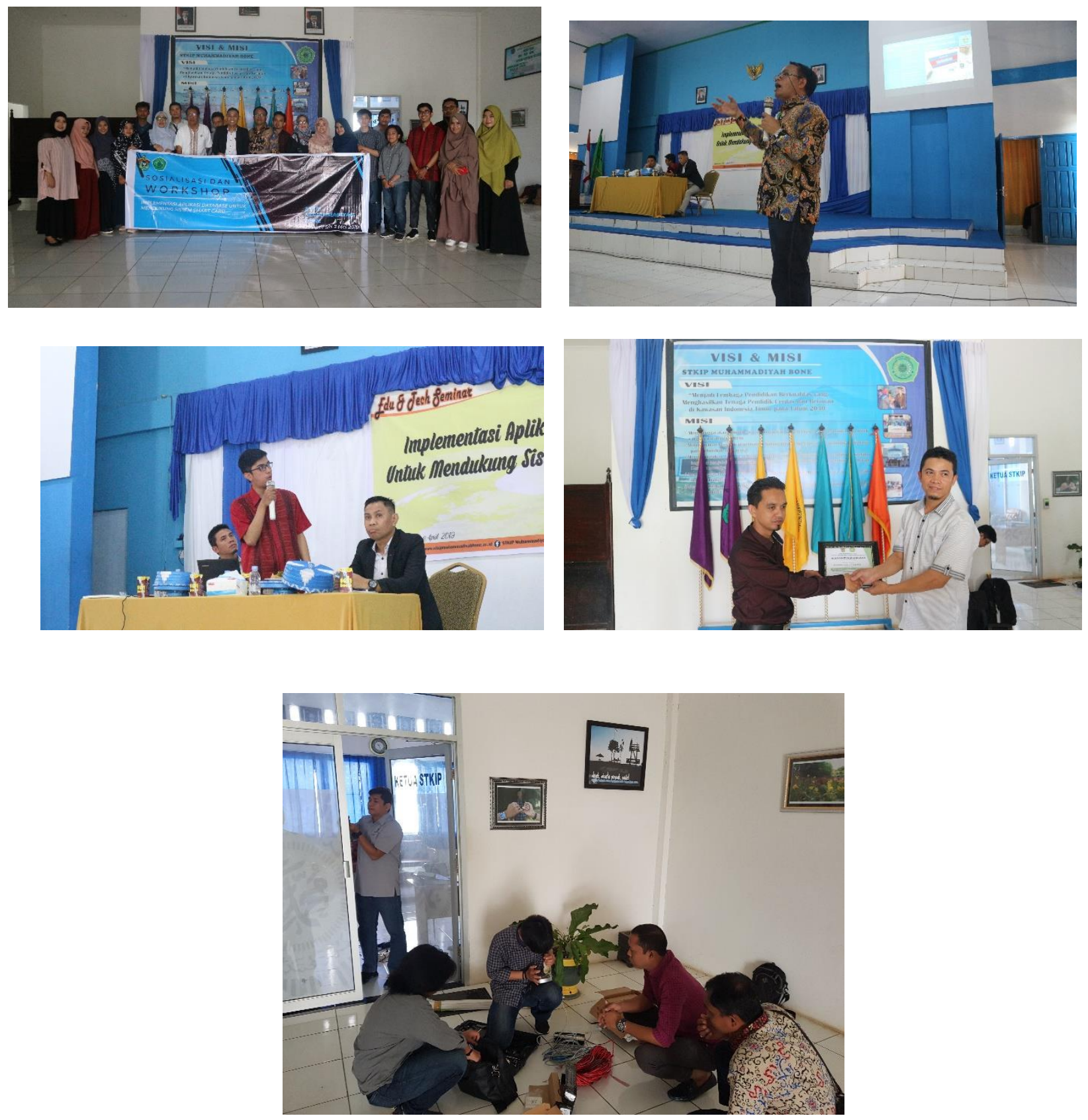

Gambar 1. Dokumentasi kegiatan pengabdian masyarakat dengan pihak kampus IAIN Bone

Dari beberapa dokumentasi diatas dapat dilihat dari gambar pertama yakni penyambutan dari jajaran pipinan kampus dan staf yang kemudian dilanjutkan sosialisasi smart campus berbasis smart card baik dari manfaat dan tujuan yang akan didapatkan jika menggunakan sistem ini. Kegiatan ini dilanjutkan tentang implementasi database dengan presentasi cara-cara dan fungsifungsi apa saja yang ditawarkan sistem smart campus ini yang berbasis smart card. Sebagai bentuk antusias dan kerjasama oleh pihak kampus STKIP Muhammadiyah Bone diberikan plakat sebagai tanda terima kasih atas kegiatan pengabdian kepada masyarakat ini. 


\section{Kesimpulan}

Hasil dari penyelenggaraan program pengabdian kepada masyarakat dengan mitra kampus STKIP Muhammadiyah Bone dapat dilihat dari antusiasme dari pihak jajaran staf kampus serta mahasiswa yang ikut pada kegiatan ini. Sebagai bentuk tanda pengabdian dari pihak tim program pengabdian kepada masyarakat Universitas Hasanuddin dilakukan instalasi dua buah unit sistem smartcard pada ruang rektor dan wakil rektor STKIP Muhammadiyah Bone.

\section{Ucapan Terima Kasih}

Penulis mengucapkan terima kasih kepada mitra yakni pihak kampus STKIP Muhammadiyah Bone atas kerjasamanya dalam pelaksanaan kegiatan pengabdian ini baik kepada jajaran petinggi kampus dan staf serta mahasiswa. Selain itu, penulis juga memberikan penghargaan yang setinggitingginya diberikan kepada Universitas Hasanuddin melalui hibah PPMU-PKM (Program Pengabdian kepada Masyarakat UNHAS-Program Kemitraan Masyarakat) yang telah mendukung kegiatan ini.

\section{Daftar Pustaka}

Putra, Dharma. 2017. Smart campus. Diakses di https://konsultasi.unud.ac.id/articles/smartcampus pada 1 Desember 2018

Wibawa, Sutrisna. 2017. Tri Dharma Perguruan Tinggi (Pendidikan dan Pengabdian Kepada Masyarakat). Rapat Perencanaan Pengawasan Proses Bisnis Perguruan Tinggi Negeri Yogyakarta. 29 Maret 2017, Yogyakarta. 